Пліш Ірина Валеріївна, директор СШДС "Лісова казка", педагогічний консультант приватної гімназії "Апогей", м. Київ, е-mail: apogey95@ukr.net

\title{
МАРКЕТИНГ ОСВІТНІХ ПОСЛУГ ЯК ЧИННИК ВПЛИВУ НА ЯКІСТЬ ОСВІТИ В УМОВАХ ЗАСТОСУВАННЯ ІНФОРМАЦЙНО- КОМУНІКАЦЙНИХ ТЕХНОЛОГІЙ В ЗАГАЛЬНООСВІТНІХ НАВЧАЛЬНИХ ЗАКЛАДАХ
}

\begin{abstract}
Анотація
У статті розглянуто особливості використання маркетингу в процесі управління якістю освіти в загальноосвітніх навчальних закладах, зокрема в школах приватної форми власності. Виокремлено важливість маркетингових досліджень для успішного управління якістю освіти навчального закладу. Маркетинг в управлінні освітою — це новий підхід до організації навчально-виховного процесу, який забезпечує якісне, ефективне навчання, зорієнтоване на формування особистості кожного учня. Проаналізовано роль маркетингу у здійсненні ефективного управління якістю освіти в загальноосвітніх навчальних закладах та його використання як джерела даних щодо відповідності реальних і прогнозованих результатів діяльності закладу освіти соціальному замовленню.

Ключові слова: навчання, маркетинг, інформаційно-комунікаційні технології, якість, школа, учень, учитель, навчально-виховний процес.

Постановка проблеми. Основним резервом оптимізації управління в освіті $€$ оволодіння керівником якомога більшою кількістю різноманітних прийомів, методів, засобів управління. Конкретна управлінська ситуація, яка виникає в процесі управління, може потребувати застосування методів або авторитарного стилю (наприклад, критична ситуація або брак часу), або демократичного стилю (колегіальне обговорення складної педагогічної проблеми), або ліберального стилю (незнання керівником особливостей колективу, висока особиста підготовленість працівників). Для здійснення ефективного управління якістю освіти у загальноосвітніх навчальних закладах (3Н3) необхідним є використання маркетингу як джерела даних щодо відповідності результатів діяльності закладу освіти (реальних
\end{abstract}


i прогнозованих) соціальному замовленню. Маркетинговий підхід вимагає від директора навчального закладу створення нових організаційних структур, прийняття й ухвалення раціональних управлінських рішень, модернізації системи управління, застосування нових сучасних прийомів і методів управління. Оперативний контроль за результатами навчально-виховного процесу $\epsilon$ неможливим без маркетингових досліджень. Розуміння важливості маркетингових досліджень для успішного управління діяльністю навчального закладу визначається необхідністю балансування між доступністю для освітніх послуг, і можливістю забезпечення їх якості.

Аналіз останніх досліджень і публікацій. Ма́ркетинг (англ.: marketing) — це діяльність, спрямована на створення попиту та досягнення цілей підприємства через максимальне задоволення потреб споживачів. Трьома головними аспектами маркетингу фахівці [1, 2, 3] вважають: аналітичний аспект (розуміння ринків); активний аспект (проникнення на ринки); ідеологічний аспект. Маркетинг освітніх послуг спрямований на сприяння кожному Н3 в підвищенні статусу на ринку освітніх послуг та здійснення підготовки кадрів відповідно до потреб ринку праці. Під маркетингом освітніх послуг Ф. Котлер i К. Фокс розуміють дослідження, планування, здійснення програм, задумів, спрямованих на те, щоб викликати добровільний обмін цінностями 3 цільовими ринками з метою досягнення прагнень навчальних закладів. На думку Т. Е. Оболенської, для навчальних закладів маркетинг — це розроблення, реалізація й оцінювання освітніх послуг шляхом установлення відносин обміну між НЗ та споживачами освітніх послуг з метою гармонізації інтересів та задоволення потреб школярів, учнів, студентів і слухачів [4].

Особливістю надання освітніх послуг є творча співпраця між учителем та учнем. Маркетинг освітніх послуг відрізняється тим, що в процесі надання освіти учень одержує додаткові знання, розширяє свій світогляд, може змінити свої цінності і погляди, перебуваючи тривалий час у контакті з вчителями, учні можуть пройнятися їх ідеалами.

Навчальний заклад, який сприймає таку філософію, суттєво змінюється - за рахунок орієнтації не тільки на чисельність учнів, учителів та навчально-матеріальну базу, а на визначені характеристики й обсяги потреб ринку праці, попиту на освітні послуги. Маркетинг освітніх послуг забезпечує найбільш продуктивне задоволення потреб: особистості — в освіті; навчального закладу - у конкурентоспроможності на 
ринку і матеріальному забезпеченні педагогічного колективу; ЗНЗ - в розвитку персоналу; суспільства - у розширеному відтворенні трудового й освітнього потенціалу країни. Концепція маркетингу освітніх послуг передбачає, що головне завдання ЗНЗ полягає у визначенні потреб та інтересів споживачів, їх задоволенні. Такий підхід до визначення концепції маркетингу освітніх послуг обумовлений особливостями ринку освітніх послуг. Цей ринок найтісніше пов'язаний, з одного боку, з ринком праці, а з іншого, — $з$ ринком науково-технічної продукції і ринком інвестицій [5]. Ринок освітніх послуг, як всякий інший ринок, передбачає надання знань, формування вмінь і навичок учнів; врахування ціни навчання; напрямів та просування цих послуг на ринок.

Формулювання мети статті (постановка завдання). На основі відомих визначень поняття "маркетинг" можна сформулювати визначення явища "маркетинг в 3Н3". За нашими спостереженнями, маркетинг у ЗНЗ - одна з важливим функцій управління (менеджменту), здійснення якої забезпечує регулювання освітніх послуг, розвиток учасників навчально-виховного процесу (НВП), формування та реалізацію їх якостей.

Об’єктами маркетингу у ЗНЗ, поряд з освітніми послугами, за твердженням фахівців, є місце розташування Н3, його навчально-матеріальна база, сформований громадський престиж, рейтинг учителів, рівень наукових досліджень, навчальнометодичне забезпечення НВП, широкий комплекс супутніх послуг $[1,4,5]$.

Перехід від адміністративно-командної до ринкової економіки обумовив такі зміни на ринку освітніх послуг ЗНЗ: ЗНЗ одержали більшу самостійність; поряд 3 державними з'явилося багато недержавних (приватної форми власності) ЗНЗ; прибуток став суттєвим джерелом розвитку ЗНЗ; вагомим джерелом одержання прибутку стала оплата навчання учнями за навчання; серед навчальних закладів виникла конкуренція за залучення учнів; з метою покращання якості освіти перед 3Н3 постала проблема розробки і реалізації маркетингових конкурентних стратегій.

Основними напрямами дій ЗНЗ у галузі маркетингу освітніх послуг є: одержання зовнішньої інформації; аналіз ситуації; аналіз конкуренції; одержання внутрішньої інформації (оперативні і статистичні дані, бухгалтерський облік навчального закладу); отримання зовнішньої інформації; дослідження ринку освітніх послуг. 
Однак, не зважаючи на важливість й актуальність маркетингу освітніх послуг, на теперішній час він ще не одержав належного розвитку. Багато українських навчальних закладів не має підрозділів маркетингу або відділів зв’язків із громадськістю. Здійснення маркетингової діяльності навчального закладу зводиться в основному до роботи приймальної комісії й обмежується часом рекламної компанії.

Упровадження ринкових відносин обумовлює необхідність розвинутої системи ефективного управління у сфері освітніх послуг ЗНЗ. Маркетингова діяльність ЗНЗ створює базу для прийняття управлінських рішень щодо підвищення якості освіти. Високий рівень освітнього маркетингу дозволить директору ЗНЗ забезпечити оптимальні умови розвитку педагогічної системи навчального закладу, розробити посадові інструкції та стандарти, найбільш ефективно управляти матеріальними i фінансовими ресурсами та керувати якістю освіти.

Найчастіше зазначеним вимогам відповідають ЗНЗ приватної форми власності. У ліцеях і гімназіях приватної форми власності (ГПФВ), як правило, в наявності високого рівня матеріально-технічна база - сучасне облаштування навчальних аудиторій, сучасне технічне та програмне забезпечення в класах інформатики, мультимедійне обладнання в предметних навчальних класах. 3 метою розвитку природної обдарованості дітей створюються спеціалізовані школи і профільні класи, гімназії та ліцеї. Зокрема, гімназія - середній загальноосвітній навчально-виховний заклад другого-третього ступеня, що забезпечує науково-теоретичну, гуманітарну, загальнокультурну підготовку обдарованих i здібних дітей [6]. У процесі встановлення громадянського суспільства важливим чинником $\epsilon$ існування альтернативних шляхів отримання освіти. 3 цієї точки зору важливим $є$ існування закладів освіти приватної форми власності, постійна їх підтримка з боку держави, органів місцевого самоврядування і суспільних організацій. Обов'язком держави $є$ створення умов рівноправного існування і функціонування навчальних закладів усіх форм власності, подолання багаторічної неузгодженості законодавства щодо їх діяльності, забезпечення для кожного громадянина можливості вільного вибору ЗНЗ, послуги якого найкраще задовольняють його особисті запити.

У рамках Європейського союзу освіта у приватному і недержавного секторах існує в різних формах, так само, як система освіти в цілому. В останні роки сектор в деяких країнах він зазнав реформ. 
Зокрема, законодавство Австрії передбачає функціонування приватних гімназій за двома основними напрямками: до першого належать гімназії, підпорядковані релігійній конфесії, а до другого - приватні гімназії. Для того щоб їх можна було відрізнити від державних навчальних закладів, чинні законодавчі документи вказують на необхідність для кожної з них використовувати певну назву (на честь особи або спільноти). Окрім того, в Австрії також пропонується навчання в альтернативних навчальних закладах (школах та гімназіях), які теж відносяться до приватного сектора освіти, однак вони не сповна реалізують державні програми. Керуючись принципом розвитку свободи кожної дитини як невід'ємного компоненту навчально-виховного процесу, управління гімназій та шкіл вважає за необхідне запровадити власні, незалежні педагогічні системи навчання. Приватні гімназії сучасної Австрії охоплюють приблизно 9 \% учнів, а 91 \% припадає на державні навчальні заклади.

Як зазначалося вище, в Україні вже давно з'явилися приватні школи, у тому числі й приватні гімназії. За свідченнями дослідників вони $є$ у кожному обласному центрі й у більшості міст з населенням від 20-ти і більше тисяч. Незважаючи на цей факт, дискусія щодо необхідності таких шкіл у нас і досі триває [7]. Законом України "Про освіту" передбачено, що гімназії, ліцеї та колегіуми створюються саме для розвитку здібностей, обдарувань і талантів дітей. Ця норма закону стимулювала відкриття навчальних закладів, покликаних відродити і примножити інтелектуальний потенціал України, дати можливість учням здобути знання понад обов'язковий загальноосвітній рівень, розкрити та сприяти реалізації їхніх індивідуальних творчих здібностей і обдарувань. За твердженням практиків у гімназіях приватної форми власності: "Дитина почувається набагато комфортніше у невеликому колективі класу. Поза сумнівом, у нашій школі діти отримують максимум уваги, а також індивідуальний підхід, адже кожна дитина особлива по-своєму. Крім цього, школа приділяє багато уваги толерантності, тобто всебічному розумінню кожної дитини, якою б специфічною вона не була" [8].

На основі вивчення досвіду діяльності вітчизняних приватних шкіл М. П. Гузик стверджує, що їх відмінність від державних не $є$ суттєвою в розумінні цілей навчально-виховного процесу. Як правило, ця відмінність полягає у чисто формальних, другорядних речах. Так, наприклад, в одних приватних школах процес навчання більш-менш індивідуалізується. В інших - створюються кращі ті чи інші 
умови для праці і відпочинку дітей. В третіх — навчають без домашніх завдань тощо. Але в усіх випадках, як правило, програми і підручники, уроки і процес навчання майже нічим не відрізняються від тих, що діють у державних школах [7, с. 36].

Перевагами ЗНЗ приватної форми власності також можна назвати вивчення додаткових дисциплін та індивідуальний підхід до кожного учня. Однак, питання про те, що краще: приватна або державна школа, залишається відкритим. Гімназія як європейський навчальний заклад середньої освіти бере початок 3 XVI століття. Безпосередніми попередниками гімназій стали школи (лаm.: scholae) при монастирях та світські школи при університетах, що з'являються 3 поч. XIII ст. переважно в Німеччині та Італії. У таких школах-гімназіях основним предметом була латина та викладався курс тривіальних наук (лаm.: trivium), куди входили граматика, логіка (діалектика) та риторика.

Отже, можна констатувати, що існує певний досвід організації управління НВП у закладах освіти як державної, так і приватної форм власності. Разом 3 тим, специфіка управління ГПФВ не виокремлена, не завжди повною мірою використовуються визначені вище можливості, які надає приватна форма власності.

3 огляду на вітчизняну політично-економічну ситуацію розвиток приватних гімназій в Україні є досить повільним. На відміну від освітніх систем інших держав, українська ще неспроможна забезпечити матеріальний ресурс хоча б для часткового фінансування багатьох приватних гімназій.

Сучасна система навчання у ГПФВ має бути спрямована на ствердження національних інтересів і відповідати потребам як особистості, так і суспільства, та опиратися на принцип дитиноцентризму. Слідом за фахівцями-практиками можемо припустити, що [7, с. 38]: приватна школа має сенс тільки тоді, коли вона не просто поліпшує державну школу в iï світоглядних, змістовних і процесуальнотехнологічних складових, а коли вона вибудовується на абсолютно іншій педагогічній системі, головною ознакою якої $є$ організація на розвиток природного таланту дитини і реалізацію іiі місії; тільки через приватну школу можна здійснити ті революційні перетворення у вітчизняній науковій i практичній педагогіці, які визволять дітей від того освітнього академічного рабства, у яке вони заганяються сучасним українським суспільством, у якому вони позбавляються головного дару таланту; приватні школи мають домогтися на повне самозабезпечення, маючи на 
увазі, перш за все, кадрове; вони мають створити свої власні центри з перепідготовки педагогічних кадрів, свої видавництва, структури, які займаються виробництвом дидактико-методичного i технічного супроводу персоніфікованого навчальновиховного процесу; приватні школи мають домогтися відновлення законного права їх батьків на ту частину з національного бюджету, яка виділяється на освіту дітей у державних школах; приватні школи мають домогтися делегування у Верховну Раду, й управління освітою на всіх рівнях своїх представників з метою захисту законних прав на їх фінансування на рівні тих норм, які існують у державних школах.

На користь гімназій свідчать результати зовнішнього тестування, які: "красномовно говорять про те, що рівень підготовки випускників гімназій і ліцеїв вищий, ніж в спеціалізованих і середніх школах. У цілому по Україні картина така: більше 30 \% випускників гімназій і ліцеїв показали відмінні результати. Вони набрали 173 і вище за бал на тестуваннях 3 математики і української мови і літератури. Причому гімназії показали дещо кращі результати з українській мови і літератури (33,8 \% відмінників), ліцеї стали безперечними лідерами з математики (майже 44 \%). Що стосується спеціалізованих шкіл, тут в середньому по Україні відмінників з обох предметів було близько $25 \%$, а ось у середніх загальноосвітніх школах їх опинилося менше $15 \% "$ [9].

Висновок. Ефективне управління якістю освіти на рівні навчального закладу неможливе без отримання результатів маркетингових досліджень. Необхідність їх проведення на рівні закладу освіти визначається важливістю отриманих результатів як сигналу зворотного зв'язку в процесі управління функціонуванням закладу. Управління ЗНЗ полягає в створенні такої організаційної системи, яка б забезпечила можливості: якомога точніше визначати актуальний стан системи, обирати вид прямого впливу так, щоб максимально прискорити перехід системи до стану, який $є$ метою. Незалежно від форми власності ЗНЗ, визначальним для досягнення цілей управління якістю освіти є наявність чітких і зрозумілих цілей функціонування Н3, стратегії його розвитку, доведення їх до учнів, батьків і персоналу закладу. Як свідчить досвід практиків, дирекція ЗНЗ повинна розробляти, удосконалювати, уточнювати, корегувати моделі своєї діяльності, спрямовувати їх на досягнення підвищення якості освіти. 


\section{Список використаних джерел}

1. Армстронг Г. Введение в маркетинг (Marketing: An Introduction) / Г. Армстронг, Ф. Котлер / 8-е изд. - М. : "Вильямс", 2007. - 832 с.

2. Дорошко M. Маркетинг в освіті та громадські зв'язки / М. Дорошко // Директор школи, ліцею, гімназії : всеукр. наук.-практ. журн. - 2009. — № 5. C. 86--94.

3. Маркетинг : підруч. / [В. Руделіус, О. М. Азарян, Н. О. Бабенко та ін. ; ред.упоряд. О. І. Сидоренко, Л. С. Макарова]. 2-е вид. - К. : Навчально-видавничий центр "Консоріцум із удосконалення менеджменту освіти в Україні", 2008. - 648 с.

4. Оболенська T. E. Маркетинг освітніх послуг: вітчизняний і зарубіжний досвід / Т. Е. Оболенська. - К. : КНЕУ, 2001. - 208 с.

5. Савченко B. A. Управління розвитком персоналу (2002) / Предмет "Менеджмент" // Із сайту "Бібліотека економіста" [Електронний ресурс]. — Режим доступу : http://library.if.ua/books/104.html.

6. Енциклопедія освіти / Акад. пед. наук України ; гол. ред. В. Г. Кремень. К. : Юрінком Інтер, 2008. - 1040 с.

7. Гузик М. П. Приватна школа може краще виховувати дітей, ніж державна // Всеукраїнський науково-практичний журнал "Директор школи, ліцею, гімназії". 2009. — № 2. - C. 35-38.

8. Школа — приватна, а проблеми? [Електронний ресурс] Із сайту Хмельницької приватної школи "Гармонія". — Режим доступу : http://www.harmonyschool.com/statti/pro-nas-v-presi/shkola-privatna-a-problemi.htm.

9. Грабовський $B$. A. Державно-громадське управління загальноосвітніми навчальними закладами на районному рівні [Текст] : автореф. дис. ... канд. наук 3 держ. управління : 25.00.02 / В. А. Грабовський. - К., 2006. - 18 с.

\section{МАРКЕТИНГ ОБРАЗОВАТЕЛЬНЫХ УСЛУГ КАК ФАКТОР ВЛИЯНИЯ НА КАЧЕСТВО ОБРАЗОВАНИЯ В УСЛОВИЯХ ПРИМЕНЕНИЯ ИНФОРМАЦИОННО-КОММУНИКАЦИОННЫХ ТЕХНОЛОГИЙ В ОБЩЕОБРАЗОВАТЕЛЬНЫХ УЧЕБНЫХ ЗАВЕДЕНИЯХ}

Плиш Ирина Валерьевна, директор СШДС "Лесная сказка", педагогический консультант частной гимназии "Апогей", г. Киев, e-mail: apogey95@ukr.net 


\begin{abstract}
Аннотация
В статье рассмотрены особенности использования маркетинга в процессе управления качеством образования в общеобразовательных учебных заведениях, в частности в школах частной формы собственности. Определена важность маркетинговых исследований для успешного управления качеством образования учебного заведения. Маркетинг в управлении образованием - это новый подход к организации учебно-воспитательного процесса, который обеспечивает качественное, эффективное обучение, ориентированное на формирование личности каждого ученика.

Ключевые слова: обучение, маркетинг, информационно-коммуникационные технологии, качество, школа, ученик, учитель, учебно-воспитательный процесс.

\section{MARKETING OF EDUCATIONAL SERVICES AS A FACTOR OF INFLUENCE ON EDUCATION QUALITY IN THE CONDITIONS OF INFORMATION AND COMMUNICATION TECHNOLOGIES APPLICATION IN THE SECONDARY EDUCATIONAL INSTITUTIONS}

Iryna V. Plish, Director of "Lisova Kazka" Secondary School, methodologist of private gymnasium “Apogey”, Kyiv, e-mail: apogey95@ukr.net

\title{
Resume
}

The article deals with the peculiarities of marketing in the process of education quality management in secondary education institutions in particular in private schools. The importance of marketing investigations for the successful education quality management in private schools is defined. The marketing in education management it's a new approach to the education process organization which provides qualified and effective education oriented on the pupil's personal development.

Key words: education, marketing, information and communication technologies, school, pupil, education process. 